[4] Cf. M. S. Newman, P. G. Scheurer, J. Am. Chem. Soc. 78, 5004 (1956), Reaction of phthalic anhydride with phenyllithium: W. E. Parham, $R$. M. Piccirilli, J. Org. Chem. 41, 1268 (1976).

[5] A. Lütringhaus, H. Gralheer, Justus Liebigs Ann. Chem. 550, 67 (1942)

[6] H. Raistrick, R. Robinson, D. E. White, Biochem. J. 30, 1303 (1936)

[7] According to the ${ }^{1} \mathrm{H}-\mathrm{NMR}$ spectrum, formation of up to a maximum of $5 \%$ of the isomer-by addition of $(6 b)$ to the sterically more hindered carbonyl group of $(S)$-cannot be ruled out.

[8] Correct analytical values were obtained for the new compounds.

\section{The Synthesis of Unsymmetrical Tetraarylporphyrins on Solid Phases $\left.{ }^{[* *}\right]$}

By Clifford C. Leznoff and Polina I. Svirskaya ["]

There has been tremendous interest recently directed toward the synthesis of model porphyrin systems related to the oxygenbinding proteins ${ }^{[1]}$. In addition, the synthesis of model dimers and higher aggregates of porphyrins are of particular interest in studies of the photo-oxidation of water to oxygen during photosynthesis ${ }^{[2]}$. The symmetrical tetraarylporphyrins had long been widely used as models in both of these systems due to their ease of preparation ${ }^{[3]}$, but some more recent sophisticated work required the synthesis of unsymmetrical tetraarylporphyrins, which were synthesized in yields ranging from $0.5-5 \%[4]$. Furthermore, the desired product could only be isolated from the many other compounds produced by extensive chromatographic separations.

Although preformed hemes and porphyrin models have been attached to insoluble supports ${ }^{[5]}$ and unusual synthetic polymers incorporating the heme function have been described ${ }^{[6]}$, the actual synthesis of a porphyrin on polymer supports from its simple precursors has not been described. Insirluble polymer supports provide a suitable means of "fishing out" a minor component from a complex reaction mixture ${ }^{1 \text { is }}$ and we have utilized these supports in this way to prepare monoblocked derivatives of a wide variety of symmetrical difunctional compounds ${ }^{(7 b)}$.

We now report that insoluble polymer supports can be used to prepare unsymmetrical tetraarylporphyrins and aid in their isolation. Thus a $2 \%$ crosslinked divinylbenzene-styrene copolymer (1) containing $1.7 \mathrm{mmol}$ of benzoyl chloride functional groups per $\mathrm{g}$ polymer ${ }^{[8]}$, was treated with 3 -hydroxybenzaldehyde (2) or 4-hydroxybenzaldehyde (3) to give the polymer-bound benzoylbenzaldehydes (4) and (5), respectively. Cleavage of (4) and (5) with $0.5 \mathrm{M}$ sodium hydroxide/ dioxane $(1: 1)$ at room temperature for $20 \mathrm{~h}$ liberated $0.73 \mathrm{mmol}$ of (2) and $1.06 \mathrm{mmol}$ of (3)/g of (4) and (5), respectively. Treatment of (4) and (5) with p-tolualdehyde and pyrrole in hot propionic acid for $1 \mathrm{~h}$ yielded upon filtration black polymers which were readily washed free of tetratolylporphyrin by extraction in a Soxhlet extractor with chloroform for $2 \mathrm{~h}$ toyield the polymer-bound unsymmetrical tetraarylporphyrins (6) and (7), respectively. Cleavage of (6) and (7) with potassium carbonate in methanol for $24 \mathrm{~h}$ yielded black powders essentially free of tetratolylporphyrin present in large amounts in a comparable solution synthesis ${ }^{[4]}$.

The black powders can be readily purified by a quick filtration through a silica column using chloroform as eluant followed by preparative thin-layer chromatography using benzene/ether/chloroform $(7: 2: 1)$ as eluant to give 5-(3-hydroxyphenyl)-10,15,20-tritolylporphyrin (8) in $2 \%$ yield and 5-(4hydroxyphenyl)-10,15,20-tritolylporphyrin (9) in $4.5 \%$ yield,

[*] Dr. C. C. Leznoff, Dr. P. I. Svirskaya

York University, Department of Chemistry

Downsview, Ontario M3J IP3 (Canada)

$\left[{ }^{* *}\right]$ This work was supported by the National Research Council of Canada.

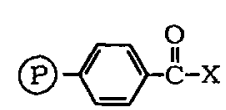<smiles>O=Cc1cccc(O)c1</smiles>

(1), $\mathrm{X}=\mathrm{Cl}$<smiles>[Y]#[W]Oc1cccc(C=O)c1</smiles><smiles>O=Cc1ccc(O)cc1</smiles>

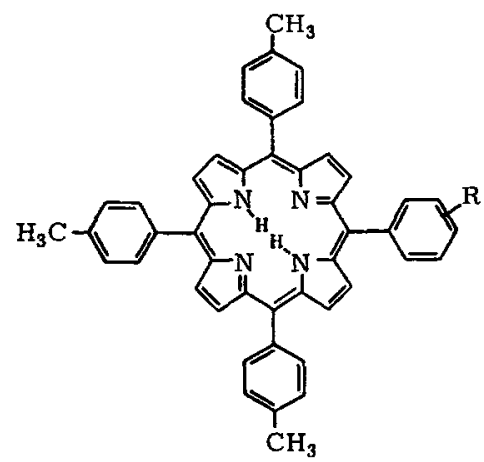

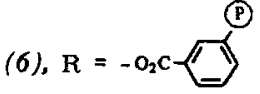<smiles>[R]COC(=[18O])c1ccc([12H])cc1</smiles>

(8), $\mathrm{R}=3-\mathrm{OH}$

(9), $\mathrm{R}=4-\mathrm{OH}$

both as purple crystals. The NMR spectra of (8) and (9) were identical with the published spectra ${ }^{[4 a]}$ and the mass spectra exhibited peaks of $672\left(M^{+}\right)$and $336\left(M^{2+}\right)$ typical of tetraarylporphyrins ${ }^{[9]}$.

CAS Registry numbers:

(2), 100-83-4;(3), 123-08-0; (8),57412-06-3; (9), 57412-08-5; p-tolualdehyde. 104-87-0; pyrrole, 109-97-7

[1] See, e.g. J. W. Buchler, Angew. Chem. 90, 425 (1978); Angew. Chem. Int. Ed. Engl. 17, 407 (1978), and references cited therein; J. P. Collman, Acc. Chem. Res, 10, 265 (1977), and references cited therein.

[2] J. H. Fuhrhop, Angew. Chem. 88, 704 (1976): Angew. Chem. Int. Ed. Engl. 15, 648 (1976); F. P. Schwarz, M. Goutterman, Z. Muljiani, D. H. Dolphin, Bioorg. Chem. 2, 1 (1972).

[3] A. D. Adler, F. Longo, J. Finarelli, J. Goldmacher, J. Assour, L. Korsakoff, J. Org. Chem. 32, 476 (1967).

[4] a) R. G. Little, J. A. Anton, P. A. Loach, J. A. Ibers, J. Heterocycl Chem. 12, 343 (1975); b) J. A. Anton, J. Kwong, P. A. Loach, ibid. 13, 717 (1976); c) S. P. Collman, C. M. Elliot, T. R. Halbert, B. S. Tourog, Proc. Nat. Acad. Sci. USA 74, 18 (1977).

[5] O. Leal, D. L. Anderson, R. G. Bowman, F. Basolo, R. L. Burwell, Jr. J. Am. Chem. Soc. 97, 5125 (1975): E. Tsuchida, K. Honda, H. Sata, Inorg. Chem. 15, 352 (1976).

[6] E. Bayer, G. Holzbach, Angew. Chem. 89, 120 (1977); Angew. Chem. Int. Ed. Engl. 16. 117 (1977).

[7] a) I. T. Harrison, S. Harrison, J. Am. Chem. Soc. 89, 5723 (1967); C. C. Leznoff, J. Y. Wong, Can. J. Chem. 50, 2892 (1972); J. M. J. Fréchet, L. J. Nujens, ibid. 54, 926 (1976); J. Y. Wong, C. Manning, C. C. Leznoff, Angew. Chem. 86, 743 (1974); Angew. Chem. Int. Ed. Engl. 13, 666 (1974); b) C. C. Leznoff, Acc. Chem. Res. II, 327 (1978).

[8] T. M. Fyles, C. C. Leznoff, Can. J. Chem. 54, 935 (1976); M. J. Farrall, J. M. J. Fréchet, J. Org. Chem. 41,3877(1976); T. M. Fyles, C. C. Leznoff, J. Weatherston, Can. J. Chem. S4, 1031 (1978).

[9] M. Meot-Ner, J. H. Green, A. D. Adler, Ann. N. Y. Acad. Sci. 206, 641 (1973).

\section{Addition of Water to $o$-Phenylethynyl-Substituted Tri- phenylphosphanes}

\section{By Werner Winter [*]}

Surprisingly, on recrystallization of the o-phenylethynylsubstituted triphenylphosphane $(1 a)^{[11 a]}$ from commercial ethanol, the triphenylphosphane oxide ( $2 a$ ) containing a stereo-

[*] Dr. W. Winter

Instifut für Organische Chemie der Universität

Auf der Morgenstelle 18, D-7400 Tübingen (Germany) 